\title{
ESTONIAN MODERN HISTORY IN THE TWENTY-FIRST CENTURY
}

\author{
Karsten BRÜGGEMANN ${ }^{\mathrm{a}}$ and Bradley D. WOODWORTH ${ }^{\mathrm{b}}$ \\ a Tallinna Ülikool, Humanitaarteaduste Instituut, Ajaloo, arheoloogia ja kunstiajaloo keskus, Narva \\ mnt 25, 10120 Tallinn, Estonia; karsten.bruggemann@tlu.ee \\ ${ }^{\mathrm{b}}$ History Program, University of New Haven, 300 Boston Post Road, West Haven, CT 06516 USA; \\ bwoodworth@newhaven.edu
}

This article presents a short overview of Estonian and international research on the nineteenth century in Estonia during the decades since the re-establishment of independence in 1991, with a focus on work published in the twenty-first century. The authors discuss the most important directions of research - socioeconomic history in rural and urban environments, Estonian nationalism and the development of ethnic milieus of Baltic Germans and Russians, the history of Estonia as part of a larger empire and, albeit very briefly, also cultural history. The authors also identify a number of topics still in need of attention by scholars.

For historians writing in European languages, the notion of writing about the nineteenth century as the period 1800 to 1900 has for several decades been supplanted by the argument that as a temporal framework, the period from the beginning of the French Revolution in 1789 to the outbreak of war in 1914 simply makes much more sense. Even for the present authors, writing about the historiography of a land which the first of these events did not immediately affect, it is a bit artificial to cut the "long nineteenth century" short since there is hardly any study on Estonian history that uses exactly the time frame from 1800 to $1900 .{ }^{1}$ For the purpose of this article, as requested by the editor, we nevertheless focus on this "arithmetic" period in order to avoid overlaps with the contributions in this special issue on early modern and twentieth century history. As is widely known, Estonia was a multinational region in the nineteenth century, and contemporary research on it is to a large degree a transnational process. Thus we include in our historiographical sketch also a number

1 For an older historiographical overview, see Брюггеман, К. Новейшая историография истории Прибалтийских губерний в составе Российской империи (XVIII-начало XX вв.): От старых стереотипов к новому осмыслению. - Россия и Балтия (3): Остзейские губернии и СевероЗападный край в политике Российской империи. 2-я половина XVIII в.-XX в. Отв. ред. А. О. Чубарьян. Институт всеобщей истории РАН, Москва, 2004, 220-245. 
of works produced by scholars who are not affiliated with Estonian research institutions.

This overview is not meant to be exhaustive. What we try to do is to cover the most relevant fields in nineteenth-century history that have been explored during the last three decades predominantly by historians. To get a more systematic impression of what has been done regarding this period we will structure our contribution thematically and not chronologically. We begin with a few general remarks introducing general histories that cover inter alia the nineteenth century (I). What follows are sections on socioeconomic history (II), nationalities (III), Estonia as part of a larger empire (IV) and concluding remarks (V), which include references to the traditionally large field of works dealing with cultural developments during the nineteenth century.

\section{I.}

To some extent, Estonian historiography struggles with a structural dilemma. The number of professional historians is small and the number of potential topics unlimited. The interest in Estonian history very often follows societal conjunctures; thus many scholars after 1991 have focused on the phenomenon of Sovietization. If during the final period of the Estonian SSR the history of the Estonian national movement in the second half of the nineteenth century was quite popular, the focus now definitively has shifted to the mid-twentieth century. On the other hand, the interest of scholars from abroad in Estonian (or, for that matter, Baltic) history often follows disciplinary conjunctures in the broader field. Even if this also serves to fill important gaps in the local historiography, it does not necessarily support research in fields underrepresented among Estonian historians. Moreover, the small number of active, publishing historians results in a kind of "individual monopoly" on certain topics, thus preventing larger debates among colleagues. And finally, serious research on the nineteenth century requires linguistic abilities a younger generation often lacks.

While Estonian historians frequently focus specifically on their primary topics, it is often scholars from abroad who produce more general histories of the country and the Baltic region, with considerable space, as a rule, devoted to the nineteenth century. If histories produced by (emigre) Estonian, (Baltic) German or Finnish authors often complement each other quite fittingly, ${ }^{2}$ general histories produced by

\footnotetext{
2 On Estonian history specifically Raun, T.U. Estonia and the Estonians. Stanford University Press, Stanford, 2001, 37-81; Zetterberg, S. Eesti ajalugu. Tlk H. Laanpere jt. Tänapäev, Tallinn, 2009, 226-355; books by Rein Taagepera, David J. Smith and Neil Taylor have a clear focus on the twentieth century. On Baltic history see, e.g., Garleff, M. Die baltischen Länder. Pustet, Regensburg, 2001, 73-86; Kasekamp, A. A History of the Baltic States. 2nd edition. Macmillan, London, 2018, 62-83; Plakans, A. A concise history of the Baltic states. Cambridge University Press, Cambridge, 2011, 170-265; Angermann, N.; Brüggemann, K. Geschichte der baltischen Länder. Reclam, Stuttgart, 2018, 181-222. With a focus on Baltic Germans Pistohlkors, G. v. Die Ostseeprovinzen unter russischer Herrschaft (1710/95-1914). - Baltische Länder. Hrsg. v. Idem. Siedler, Berlin,
} 
Russian authors often reveal an apologetic position concerning St. Petersburg's imperial rule in the Baltic Sea area and even promote a kind of Russian Kulturträgertum. ${ }^{3}$

The major comprehensive work by Estonian historians is the collective volume Eesti ajalugu V (2010), which covers the period from the early nineteenth century to $1918 .{ }^{4}$ Even if this volume arguably suffers from a more academic point of view by its lack of scholarly references, it provides a detailed and authoritative overview of the century. Also recently published is a history of Estonia by a single (Estonian) author: the renowned medievalist and early modernist Enn Tarvel. His Eesti rahva lugu, however, sees the nineteenth century primarily from the perspective of the Estonians' fight for emancipation against imperial and local foreign rule. ${ }^{5}$

More specifically, the "Russian time" (vene aeg), i.e. the period from the Great Northern War to the Russian Revolution, is discussed in quite a number of collected editions published in Estonian, English and German. These include more loosely connected works covering this particular period of Estonian history, but also topically focused collections concerning, e.g., relations with Russia or particular aspects of imperial rule and local responses. ${ }^{6}$

2002, 265-450. Currently in preparation: Das Baltikum: Geschichte einer europäischen Region. Bd. 2: Vom Beginn der Frühen Neuzeit bis zur Gründung der modernen Staaten. Hrsg. v. K. Brüggemann, D. Henning, R. Tuchtenhagen. Hiersemann, Stuttgart, 2021.

3 See, especially, Федосова, Э. П. Россия и Прибалтика: культурный диалог. Вторая половина XIX-начало XX века. Институт российской истории, Москва, 1999, and, from a contemporary imperial point of view Воробьева, Л. В. Прибалтика на разломах международного соперничества. ФИВ, Москва, 2013, 190-344.

4 Eesti ajalugu V. Pärjusorjuse kaotamisest Vabadussõjani. Peatoim S. Vahtre, tegevtoim T. Karjahärm, T. Rosenberg. Ilmamaa, Tartu, 2010. An early publication covering the period: Eesti ajalugu ärkamisajast kuni tänapäevani. Toim S. Õispuu. Koolibri, Tallinn, 1992. See the collection of documents: Ajalooarhiivi varasalvest. Dokumente Eesti ajaloost Rootsi ja Vene ajal (17.-20. sajandi algul). Toim K. Lust, E. Küng, T. Tannberg, T. Türna. Eesti Ajalooarhiiv, Tartu, 2011.

5 Tarvel, E. Eesti rahva lugu. Varrak, Tallinn, 2018, 148-170 (on nineteenth century).

6 Seltsid ja ühiskonna muutumine: Talupojaühiskonnast rahvusriigini. Artiklite kogumik. Toim E. Jansen, J. Arukaevu. Eesti Ajalooarhiiv, Eesti TA Ajaloo Instituut, Tartu, Tallinn, 1995; Estland und Russland: Aspekte der Beziehungen beider Länder. Hrsg. v. O. Mertelsmann. Kovač, Hamburg, 2005; Vene aeg Eestis: Uurimusi 16. sajandi keskpaigast kuni 20. sajandi alguseni. Koost T. Tannberg. (Eesti Ajalooarhiivi toimetised, 14 (21).) Eesti Ajalooarhiiv, Tartu, 2006; Vene impeerium ja Baltikum: Venestus, rahvuslus ja moderniseerimine 19. sajandi teisel poolel ja 20. sajandi alguses, I. Toim T. Tannberg, B. Woodworth. (Eesti Ajalooarhiivi toimetised, 16 (23).) Eesti Ajalooarhiiv, Tartu, 2009; Vene impeerium ja Baltikum: Venestus, rahvuslus ja moderniseerimine 19. sajandi teisel poolel ja 20. sajandi alguses, II. Toim T. Tannberg, B. Woodworth. (Eesti Ajalooarhiivi toimetised, 18 (25).) Eesti Ajalooarhiiv, Tartu 2010; Eesti ajaloost 19.-20. sajandil: Uurimusi historiograafiast, allikaõpetusest ja institutsioonidest. Toim T. Tannberg. (Eesti Ajalooarhiivi toimetised, 19 (26).) Eesti Ajalooarhiiv, Tartu, 2012; Russland an der Ostsee: Imperiale Strategien der Macht und kulturelle Wahrnehmungsmuster (16. bis 20. Jahrhundert) = Russia on the Baltic: Imperial strategies of power and cultural patterns of perception (16th-20th centuries). Ed. by K. Brüggemann, B. Woodworth. (Quellen und Studien zur baltischen Geschichte, 22.) Böhlau, Cologne et al., 2012; Wandel und Anpassung in der Geschichte Estlands: 16.-20. Jahrhundert. Hrsg. v. K. Brüggemann. (Nordost-Archiv, 22/2013.) Nordost-Institut, Lüneburg, 2014; Uutmoodi ja paremini: Ühiskondli- 
II.

One of the most significant works of Estonian history published in the last twenty years is the final book by Ea Jansen (1921-2005), Eestlane muutuvas ajas, published posthumously in $2007 .^{7}$ This monumental work is easily the best book on the social history of Estonians in the long nineteenth century. Jansen was influenced by the work of historians of modern Europe who in the last decades of the twentieth century, following in the wake of Jürgen Habermas's work Strukturwandel der Öffentlichkeit (1962), looked anew at forms of social engagement in the nineteenth century. The book deals not only with Estonians, but examines the changing nature of the relationship between Estonians and Baltic Germans throughout this period of modernization. Social differentiation and stratification among Estonians Jansen sees as central. As Estonians were increasingly active in public life, including voluntary associations, the press, and local self-government, what had been a "bourgeois public sphere" became a "civil public sphere." By the end of the nineteenth century an Estonian civil society had formed.

Jansen's aim in her magnum opus goes beyond describing Estonians in changing times. She writes of the longing that the nineteenth-century Baltic German novelist Johanna Conrad had for the "children of the same land" to enjoy a shared Baltic identity. Jansen writes: "People living in the same land, in the same geopolitical atmosphere, were connected to each other through many ties, their everyday ways of thinking were stamped by the same climate and natural environment, and they had the same neighbors and were in constant contact with each other." As she seeks to understand the persistent social divisions in the Baltic provinces, Jansen avoids laying unidirectional blame, pointing to an "autocratic system" to which all were subject, but also to the separateness of Estonian rural folk (including those who increased in wealth later in the century) and to the Baltic German landowning and urban elites, who were "insufficiently modernized" as a consequence of the politically backward tsarist state. ${ }^{8}$ While separation was certainly furthered by the language barrier between Estonians and Germans, social divergence (lahknemus) had yet deeper causes: "As society modernized, manifesting in industrialization, the development of market relations and a money economy, and alterations in the sphere of communication, the German upper classes and the Estonian peasants became mutually 'other,' and the change that both underwent did not create sufficient conditions for rapprochement and blending."

kest muutustest 18. sajandil ja 19. sajandi algul. Toim K. Kaju. (Rahvusarhiivi toimetised, (33).) Eesti Ajalooarhiiv, Tartu, 2018

7 Jansen, E. Eestlane muutuvas ajas: Seisusühiskonnast kodanikuühiskonda. Eesti Ajalooarhiiv, Tartu, 2007.

8 Jansen's approach is criticized by Kersti Lust. See Lust, K. Rahvuse saamiseks lugu. - Sirp: Eesti kultuurileht, 19.10. 2007.

9 Jansen, E. Eestlane muutuvas ajas, 453, 457. Johan Eellend has drawn attention to the merging of interests of German manor owners and the growing number of Estonian farmers during the 1890s, especially concering problems in marketing products and finding farm workers. The ideal circumstances of an Estonian farmer as envisioned by Estonian agrarian journals of that period were 
Kersti Lust's extensive scholarly output has focused on the peasant agrarian economy in Estland and Livland (as well as Kurland) from the peasant emancipations in the second decade of the nineteenth century up to the eve of the First World War. Lust emphasizes the deleterious role of local traditional social hierarchies, especially noble landlord intransigence and insistence by Baltic German lords on their dominant position. Reforms aimed at state-owned peasants in the tsarist Baltic provinces introduced during the reign of Nicholas I helped weaken the feudal order in the countryside and strengthened the legal and economic position of peasants. In times of famine, however, like in the $1840 \mathrm{~s}$, the communities were again dependent on the manor lords, who eventually were obliged by the central authorities to disburse grain to the needy. However, Lust also maintains that peasant communities were reluctant to ask for loans, fearing this could ruin the farms. On the other hand, she demonstrates how capable peasants were in adopting modernizing practices in agriculture. ${ }^{10}$ Ülle Tarkiainen emphasizes Enlightenment-inspired agricultural innovations and modernization by the landowning Baltic German elites and deals with the traditional ways rural communities cared for the elderly and the poor. She argues that despite all changes in the countryside during the nineteenth century, the relative proportion of the poor in need of assistance among the rural population increased relatively little, and peasants tried everything to remain independent of the assistance of the community. ${ }^{11}$ A collective monograph has recently shed light on the process of the purchase of farms by peasants in Pärnu county. Among other aspects, the authors draw attention to the differences in the attitude of peasants in economically developed

markedly different from the perceived reality on manorial estates: he would have "tilled the soil by himself and had a relationship to his workers characterized by mutual respect and honour." Eellend, J. Unity through modernity: The agrarian media and the national question at the turn of the 20th century. - Nordost-Archiv 2009, 18, 25-43 (quote 40); Eellend, J. Cultivating the rural citizen: Modernity, agrarianism and citizenship in late Tsarist Estonia. (Södertörn Doctoral Dissertations, 18; Studia Baltica, 2.) Stockholm University, Stockholm, 2007.

${ }^{10}$ Such as Lust, K. The impact of the Baltic emancipation reforms on peasant-landlord relations: A historiographical survey. - Journal of Baltic Studies, 2013, 44, 1, 1-18; Lust, K. Pärisorjast päriskohaomanikuks: talurahva emantsipatsioon eestikeelse Liivimaa kroonukülas 1819-1915, Eesti Ajalooarhiiv, Tartu, 2005; Lust, K. Kiselev's reforms of state peasants: The Baltic perspective. - Journal of Baltic Studies, 2008, 39, 1, 57-71; Lust, K. Die Innovationsbereitschaft der livländischen Bauern und die Agrarreformen im 19. Jahrhundert. - Zeitschrift für Ostmitteleuropa-Forschung, 2006, 55, 4, 510--525. More specifically on famine relief: Lust, K. Feeding the landless in post-emancipation Livland during times of famine (1840s-1860s) - Slavonic and East European Review, 2014, 92, 1, 81-106; Lust, K. Kui suured näjahädad tabasid Eesti talurahvast 19. sajandil? - Tuna 2017, 2, 139 145; Lust, K. Die Rolle der Gutshöfe bei der Hungerhilfe für die livländischen Bauern in den Krisenjahren 1841-1847. - Zeitschrift für Ostmitteleuropa-Forschung, 2012, 61, 2, 219-246; Lust, K. Providing for the hungry? Famine relief in the Russian Baltic province of Estland, 1867-9. - Social History, 2015, 40, 1, 15-37; Võitlus näljaga. 19. sajandi näljahädad Eesti külas. Dokumentide kogumik. Toim K. Lust. Rahvusarhiiv, Tartu, 2015. See also Seppel, M. Vene keskvalitsuse kartulikampaania Eesti- ja Liivimaal 1840 aastatel. - Õpetatud Eesti Seltsi aastaraamat 2013, 121-166.

11 Tarkianen, Ü. Vaestehoolekanne Põhja-Liivimaa külaühiskonnas 19. sajandil. - Ajalooline Ajakiri, 2016, 2 (156), 215-244; Tarkianen, Ü. Estland and Livland as test areas for agricultural innovation. - Russland an der Ostsee, 345-364. 
regions like Mulgimaa and poorer parishes in the northwest of the county. ${ }^{12}$ In recent years, both Tarkianen and Lust have dealt increasingly with questions of peasants' private life, family relations, and questions of inheritance and emphasized issues connected with land-ownership by women. ${ }^{13}$

In recent decades Tallinn has clearly been the focus of research in urban environments. ${ }^{14}$ Ralph Tuchtenhagen's and Karsten Brüggemann's German-language history of the city (2011) was quickly translated into Estonian. ${ }^{15}$ The passages on the nineteenth century emphasize topics such as modernization and the growing tensions related to the emergence of different ethnic groups, but also the role of the city in imperial (Russian) memory. A much more comprehensive story of the city's development is given in the third volume of a new history of Tallinn that covers the period from 1710 to 1917. Special chapters inform about the demographic situation, the Magistrat and its relations with Petersburg, the development of the economy (craft, trade and industry) and jurisprudence, but also about the upholding of defence structures and military obligations. Readers learn about the church life of differing confessions and the cultural achievements of various ethnic groups. The school system is discussed, as is the health system and the development of city space and architecture. $^{16}$

In his analysis based on archival research, Bradley Woodworth approaches Estonian urban spaces in the nineteenth century as inherently multiethnic. ${ }^{17}$ His work

${ }^{12}$ Laur, M., Lust, K., Pirsko, P., Tarkiainen, Ü. Talude päriseksostmine: Pärnumaa andmestiku põhjal. Eesti Ajalooarhiiv, Tartu, 2014.

${ }^{13}$ Tarkiainen, Ü. Varaühisus või varaühendus? Abikaasade varalised suhted ja naiste maaomand Järvamaal 19. sajandi lõpul ja 20. sajandi alguses. - Eesti ajaloost 19.-20. sajandil, 113-143; Tarkiainen, Ü. Talude pärimine Eesti agraarühiskonnas 19. sajandi lõpul ja 20. sajandi alguses. - Vene impeerium ja Baltikum I, 255-282; Lust, K. Bitter fruits of “a merry life?" Survival chances of children born out of wedlock in nineteenth-century rural Estonia. - Journal of Family History, 2020, 45, 1, 20-38; Lust, K. A not so undesirable status? Widowhood options and widows' living conditions in post-emancipation rural Estonia. - The History of the Family (publ. so far online https://doi.org/10.1080/1081602X.2020.1796749). On Baltic Germans see Plath, U. Stille im "Haus": Hausvater, Verwalter und transnationale Gesellung auf dem baltischen Gutshof zwischen 1750 und 1850. - Ehe. Haus. Familie: Strategien und Inszenierungen häuslichen Lebens 1750-1850. Hrsg. v. I. Schmidt-Voges. Böhlau, Köln, 2010, 179-207.

${ }^{14}$ On the history of Tartu see Tartu: Ajalugu ja kultuurilugu. Toim H. Pullerits, U. Tõnisson, A. Liim, A. Andresen. Tartu Linnamuuseum, Tartu, Ilmamaa, 2005. Continuing the tradition of demographic historian Heldur Palli (1928-2003), who produced valuable studies in Soviet times on urban demographics, see Berendsen, V., Maiste, M. Esimene ülevenemaaline rahvaloendus Tartus 28. jaanuaril 1897. Eesti Ajalooarhiiv, Tartu, 1999. A doctoral dissertation has been written based on this collection of data: Jaadla, H. Mortality in the Lutheran population of Tartu at the end of the 19th century. (Sotsiaalteaduste dissertatsioonid, 109.) Tallinn, Tallinn University, 2016; see also Gortfelder, M., Puur, A. Demograafiline nüüdisajastumine Eestis: 1850-1899 sündinud naiste emaduslugude analüüs. - Tuna, 2019, 1, 19-38.

${ }^{15}$ Brüggemann, K., Tuchtenhagen, R. Tallinna ajalugu. Tlk K. Kaugver, T. Vassiljeva. Varrak, Tallinn, 2013.

${ }^{16}$ Tallinna ajalugu. III, 1710-1917. Toim T. Kala, L. Kõiv, O. Liivik. Tallinna Linnaarhiiv, Tallinn, 2019.

${ }^{17}$ Woodworth, B. Civil society and nationality in the multiethnic Russian empire: Tallinn / Reval, 1860-1914. Indiana University dissertation, 2003. 
on Tallinn in this period draws parallels between Estonians, Baltic Germans, and Russians in the city in associational life and civic engagement and argues that civil society and nationality developed in tandem. This is proven also by Astri Schönfelder, who in her monograph on political mobilization during election campaigns in smaller Estonian cities convincingly demonstrates how participants in Estonian civil society during the final decades of the nineteenth century and early twentieth century learned how to carry out their own agenda in a multicultural environment. With the parliamentary future of the country in mind, even more decisive than national competition was that Estonian national elites learned to use their position in the opposition as an effective tool to win majorities, form coalitions, and find pragmatic compromises. ${ }^{18}$

The key work on the largely urban group that is the intelligentsia, by Toomas Karjahärm and Väino Sirk, Eesti haritlaskonna kujunemine ja ideed 1850-1917, provides descriptions of the education and activities of this group and also their socio-political views. ${ }^{19}$ Since the publication of this work in 1997, more detailed studies have begun to be undertaken. The non-noble urban population, particularly in Tartu, has been the focus of attention of Lea Leppik, who emphasizes social mobility and professionalization among the Estonian population. ${ }^{20}$ Bradley Woodworth has drawn attention to a group that has received little study: Estonians who worked within tsarist state offices. ${ }^{21}$

Compared to the traditional strong focus on Estonian peasantry in historiography, those who left the countryside in order to look for better opportunities in the emerging industrial centers have been studied much less. To be certain, scholarly work on the plight of the Estonian peasantry was ideologically supported during the Soviet period and could be regarded by local historians as writing national history. ${ }^{22}$ A bit provocatively, one might say that the Estonian proletariat as an object for social history is still hidden behind the walls of Soviet idealizations of class-based history and thus seen as a topic not related enough to the "national" past. ${ }^{23}$ Moreover, contemporary trends in history writing do not favor socio-economic history

${ }^{18}$ Schönfelder, A. Deutsche Bürger “contra homines novi”: Die städtischen Wahlkämpfe in Estland 18771914. (Hamburger Beiträge zur Geschichte des östlichen Europa, 22.) Dr. Kovač, Hamburg, 2016.

${ }^{19}$ Karjahärm, T., Sirk, V. Eesti haritlaskonna kujunemine ja ideed 1850-1917. Eesti Entsüklopeediakirjastus, Tallinn, 1997; Sirk, V. Haritud eestlased Eesti linnades 1850.-1880. aastatel. - Acta Historica Tallinnensia, 1998, 2, 3-34.

${ }^{20}$ Leppik, L. Kalefaktoripojast professoriks: Tartu ülikooli teenistujate sotsiaalne mobiilsus 1802 1918. Kleio, Tartu, 2011.

${ }^{21}$ Woodworth, B. Multiethnicity and Estonian Tsarist state officials in Estland province, 1881-1914. - Russian bureaucracy and the state: Officialdom from Alexander III to Putin. Ed. by D. K. Rowney, E. Huskey. Palgrave-Macmillan, Basingstoke, 2009, 72-88; interesting insights in the archival holdings is provided by Davõdov, I. Ametnike teenistuslehed kui ajalooallikas Eestimaa kubermanguvalitsuse arhiivifondi näitel. - Tuna, 2016, 1, 20-41.

${ }^{22}$ Kivimäe, J. Re-writing Estonian history? - National history and identity: Approaches to the writing of national history in the North-East Baltic region, nineteenth and twentieth centuries. Ed. by M. Branch. (Studia Fennica, 6.) Finnish Literary Society, Helsinki, 1999, 209.

${ }^{23}$ On the rural proletariat, see Lust, K. Agricultural labourers and their wages in Estland in 18851913. - Ajalooline ajakiri, 2007, 3/4 (121/122), 393-409. 
and might not seem attractive enough for younger students of history. ${ }^{24}$ But it is still striking that not even the aforementioned new Tallinna ajalugu has a special chapter on the Tallinn port, dockworkers, sailors and their (transnational) Lebenswelten in Tallinn, including, e.g., a thorough study of prostitution, smuggling, and other ways of defying the rules in this liminal environment. ${ }^{25}$

Maie Pihlamägi, one of the few economic historians in Estonia, focuses on urban social environments. Her monograph on industrialization since the 1870s shows how tightly the development of large-scale industry in Estonian urban centers was connected to the same process in the Russian Empire that provided the major market for products from the provinces, with textile industry as the major branch. ${ }^{26}$ Pihlamägi has also studied the working conditions in larger enterprises such as the famous textile factory Kreenholm - site of a major strike in 1872 - and the social life of workers. ${ }^{27}$ The Kreenholm strike was also studied in a broader imperial context by the late American historian Reginald Zelnik. ${ }^{28}$

In recent decades, historians have increasingly looked for new and hitherto unstudied topics. A few examples from Estonian urban history might serve as illustrations. Lea Leppik has discovered the fascinating story of how money was made out of Tartu's waste. The establishment of a poudrette factory by entrepreneur Gustav Post both solved the city's waste problem and made Post a rich man when his factory's product - a fertilizer mix of dry night soil - sold quite well..$^{29}$ Another innovative topic in urban studies is the development of seside resorts in coastal cities such as Pärnu, Haapsalu, and Narva,${ }^{30}$ including research on passenger traffic from the port of Tallinn. ${ }^{31}$

${ }^{24}$ Another case in point is the history of foreign trade; see the dissertations Värä, E. Kaubandussidemed Soome suurvürstiriigi ja Eesti alade vahel aastail 1809-1865. (Tallinna Ülikool. Humanitaarteaduste dissertatsioonid, 15.) Tallinna Ülikool, Tallinn, 2013; Vinnal, H. Turusidemed: Kaubandus, kommunikatsioon ja lõimumine Lääne- ja Põhjamere regioonis, c. 1730-1830. (Dissertationes historiae Universitatis Tartuensis, 42.) Tartu Ülikooli Kirjastus, Tartu, 2019.

${ }^{25}$ An outsider in the field, a German maritime historian, produced a story of the Tallinn port and its need for ice-breakers: Ostersehlte, C. Eisbrecher vor Reval: Die Flotte des Revaler Börsenkomitees. (Schriften der Baltischen Historischen Kommission, 23.) LIT, Berlin, 2020. On maritime history see also Vunk, A. Puust laevad ja rauast mehed: Pärnu ja Liivi ranna purjelaevad. Argo, Tallinn, 2018.

${ }^{26}$ Pihlamägi, M. Eesti industrialiseerimine 1870-1940. Teaduste Akadeemia Kirjastus, Tallinn, 1999.

${ }^{27}$ Pihlamägi, M. Tsaari-Venemaa sotsiaalpoliitika Kreenholmi ja Nikolski puuvillamanufaktuuri näitel. - Acta Historica Tallinnensia, 2007, 11, 48-70; Pihlamägi, M. Tööliste osalemine seltsielus 19. sajandi teisel poolel ja 20. sajandi algul. - Seltsid ja ühiskonna muutumine, 136-151.

${ }^{28}$ Zelnik, R. Law and disorder on the Narova river: The Kreenholm strike of 1872 . University of California Press, Berkeley, 1995.

${ }^{29}$ Leppik, L. Das Geschäft mit der Poudrette: Zur sanitären Frage in Dorpat im späten 19. und frühen 20. Jahrhundert. - Forschungen zur baltischen Geschichte, 2016, 11, 113-128.

${ }^{30}$ Kivimäe, J., Kriiska, I., Põltsam, I., Vunk, A. Merelinn Pärnu. Pärnu Linnavalitsus, Pärnu, 1998; Kask, T. Der Kurort Pärnu (Pernau) Ende des 19. und Anfang des 20. Jahrhunderts: Die "kollektive Strandschwärmerei” oder Die Entdeckung der Meeresstrände an der Ostküste der Ostsee. - Tourismus im Ostseeraum. Hrsg. v. K. Brüggemann. (Nordost-Archiv, 20/2011.) Nordost-Institut, Lüneburg, 2012, 53-84; Haapsalu kuurort 185 = Haapsalu resort 185. Toim A. Lepp. Läänemaa Muuseum, Haapsalu, 2011; Стрельков, В. В. Золотое кольцо Гунгербурга. Курорт НарваЙыэсуу. Сотис, Санкт-Петербург 2007. General contributions include Wilhelmi, A. Badekulturen für Männer und Frauen. Strandleben in den Ostseeprovinzen des Russischen Reichs im 19. und 20. 
In the field of the history of education, two large multivolume studies were completed in the first decade of the new millennium. The second volume of the late Endel Laul's (1927-2014) projected four-volume history Eesti kooli ajalugu appeared in 2010, with additional scholars included as co-authors. ${ }^{32}$ The volume's some 650 pages of text examine the period from the national awakening in the $1860 \mathrm{~s}$ to the end of the tsarist era in 1917. The scope of the book is vast, including educational policy; primary, secondary, and occupational schools and school networks; institutional development of schools and what was taught; pedagogical thought; teacher training; and the lived experience of pupils and teachers. Education of nonEstonians is also examined. The authors' decades of work in the history of education in Estonia make this a work of enduring value. The other extensive multivolume study was completed by the late Lembit Andresen (1929-2016) covering specifically the history of rural primary schools (rahvakoolid), including a volume on the nineteenth and early twentieth century. ${ }^{33}$

The extensive work of Väino Sirk on the history of education during the long nineteenth century includes a discussion of terminology and typology used by contemporaries, detailed articles on the meaning of education for the protagonists of the national movement, and an interesting analysis of the differing strategies employed by Estonians and Baltic Germans to respond to the introduction of Russian in the education system during the era of Alexander III. ${ }^{34}$ This topic has also been studied, with a focus on Baltic German elites, by Indrek Kiverik, who seeks to understand how in practical terms Russian was introduced on the school-level and in administration..$^{35}$

Jahrhundert. - Seebäder an der Ostsee im 19. und 20. Jahrhundert. Hrsg. v. O. Kurilo. (Colloquia Baltica, 18.) Meidenbauer, München, 2009, 151-167; Brüggemann, K. Einleitende Überlegungen zu einer Geschichte des Tourismus im Ostseeraum am Beispiel der russischen Revalreise in der ersten Hälfte des 19. Jahrhunderts. - Tourismus im Ostseeraum, 9-33.

${ }^{31}$ Saar, T. Reisilaevaliiklus Tallinna sadamas aastatel 1837-1860. - Tuna, 2019, 3, 22-43.

${ }^{32}$ Laul, E., Elango, A., Liim, A., Sirk V. Eesti kooli ajalugu: Kaugemast, minevikust, tänapäevani. Kd 2: 1860. aastaist 1917. aastani. Teaduste Akadeemia Kirjastus, Tallinn, 2010.

${ }^{33}$ Andresen, L. Eesti rahvakooli ja pedagoogika ajalugu, III: Koolireformid ja venestamine. Avita, Tallinn, 2002. See also Andresen, L. Eesti kooli ajalugu: Algusest kuni 1940. aastani. Avita, Tallinn, 1995, 2003. About the early decades of the nineteenth century Andresen, A. Die kirchliche Schulpolitik im Gouvernement Estland im 18./19. Jahrhundert. - Schulwesen im Baltikum. Hrsg. v. D. Kühn. (Baltische Seminare, 8.) Carl-Schirren-Gesellschaft, Lüneburg, 2005, 67-73.

${ }^{34}$ Sirk, V. Balti talurahvakoolist rahvuskooli lävele: Terminoloogilisi ja tüpoloogilisi vaatlusi. - Acta Historica Tallinnensia, 2010, 15, 51-72; Sirk, V. Venemaa haridusministeerium kui müüt ja möödapääsmatus: Haridustemaatikast eestlaste 1864. ja 1881. aasta suurmärgukirjades. - Tuna, 2016, 2, 32-41; Sirk, V. Rahvakooli juhtimise ja järelvalve probleem eesti ühiskondliku liikumise põhidokumentides ning pedagoogilises kirjasõnas (ärkamisajast esimese maailmasõjani). - Acta Historica Tallinnensia, 2013, 19, 3-26; Sirk, V. Rahvakoolisüsteemi institutionaalsed probleemid ärkamisaja eesti mõtteloos (1860.-1880. aastad). - Acta Historica Tallinnensia, 2011, 16, 86-108; Sirk, V. Radikalisierung und Ethnisierung: Bildungspolitische Strategien der Esten und Deutschbalten in Reaktion auf die Reformen unter Alexander III. (Mitte der 1880er Jahre bis 1914). - Wandel und Anpassung, 112-139.

${ }^{35}$ Kiverik, I. Der politische Kampf um das Bildungswesen der Esten im 19. Jahrhundert. - Schulwesen im Baltikum, 51-66; Kiverik, I. Baltisakslased ja Vene riigivõim 19. sajandi teisel poolel: Vene 
Lea Leppik has also shown that education served as a powerful tool in achieving social mobility, which was especially true for women, and has analyzed more broadly the role of Tartu University in this process. ${ }^{36}$ General information on the history of the university during tsarist times ${ }^{37}$ has been supplemented by biographies of the first rectors, Georg Friedrich Parrot and Gustav von Ewers, ${ }^{38}$ as well as by studies on the particular environment of the university and its students. ${ }^{39}$ The impact on imperial science of one of the leading scientists of Tartu University in the nineteenth century, Karl Ernst von Baer, has been studied by Erki Tammiksaar, ${ }^{40}$ and the development of juridical education in Tartu is outlined by Marju-Luts Sootak and Toomas Anepaio. ${ }^{41}$

keele kasutuselevõtmisest Balti kubermangude ametiasutustes ja koolides. - Vene impeerium ja Baltikum I, 11-68.

${ }^{36}$ Leppik, L. Kõrgharidus sotsiaalse mobiilsuse tegurina pikal 19. sajandil. - Õpetatud Eesti Seltsi aastaraamat 2012, 232-256; Leppik, L. Über Bildungsmöglichkeiten von Frauen im Russischen Reich. Das Beispiel der Universität Dorpat bis 1905. - Bildungskonzepte und Bildungsinitiativen in Nordosteuropa (19. Jahrhundert). Hrsg. v. A. Wilhelmi. (Veröffentlichungen des Nordost-Instituts, 13.) Harrassowitz, Wiesbaden, 2011, 323-338; Leppik, L. Die Universität Dorpat im livländischen Stilleben: Ihre sozialpolitische Rolle im ersten Drittel des 19. Jahrhunderts. - Zwischen Aufklärung und baltischem Biedermeier, 131-164.

${ }^{37}$ Universitas Tartuensis 1632-2007. Toim H. Piirimäe, T. Hiio. Tartu Ülikooli kirjastus, Tartu, 2007, 109-253 (on the nineeteenth century). See also the dissertations Дубьева, Л. Историческая наука в Тартуском университете в конце XIX-начале XX вв. (Dissertationes historiae Universitatis Tartuensis, 12.) Tartu Ülikooli Kirjastus, Tartu, 2006; Tamul, S. Eraalgatuslikest stipendiumidest Tartu Ülikoolis 1802-1918. (Dissertationes historiae Universitatis Tartuensis, 14) Tartu Ülikooli Kirjastus, Tartu, 2007.

${ }^{38}$ Tohvri, E. Georges Frédéric Parrot: Tartu Keiserliku Ülikooli esimene rektor. Tartu Ülikooli Kirjastus, Tartu, 2019; Leppik, L. Rektor Ewers: Monograafia. Eesti Ajalooarhiiv, Tartu, 2001.

${ }^{39}$ Leppik, L. The multicultural urban space and the University of Tartu in the 19th century. - The Baltic as a multicultural world: Sea, region and peoples. Ed. by M. Lehti. BWV, Berlin, 2005, 131153; Leppik, L. Võim ja vaim Tartu tudengite duellidest. - Tuna, 1999, 3, 11-15; Hiio, T. Vene üliõpilaskorporatsioonist venestamiseni: Tartu saksa korporatsioonid ning üliõpilaskonna seisuslikud, ideelised ja rahvuslikud vähemusrühmad 1820.-1890. aastatel. - Vene impeerium ja Baltikum I, 127-203; Hiio, T. Tartu ülikooli üliõpilaskond 1802-1855: Päritolu ja sotsiaalne koosseis. - Eesti ajaloost 19.-20. sajandil, 9-58.

40 Tammiksaar, E. The contribution of Karl Ernst von Baer to the study of ethnic minorities in the Russian empire, 1819-1878. A case study. - Defining self: Essays on emergent identities in Russia seventeenth to nineteenth centuries. Ed. by M. Branch. (Studia Fennica. Ethnologica, 10.) Suomalaisen Kirjallisuuden Seura, Helsinki, 2009, 139-151.

${ }^{41}$ Luts-Sootak, M. Der lange Beginn einer geordneten Juristenausbildung an der deutschen Universität zu Dorpat (1802-1893), and Anepaio, T. Die russische Universität in Jur'jev (1889-1918). Juristenausbildung in Osteuropa bis zum Ersten Weltkrieg. Hrsg. von Z. Pokrovac. (Studien zur europäischen Rechtsgeschichte, Bd. 225; Rechtskulturen des modernen Osteuropa. Traditionen und Transfers, Bd. 3.) V. Klostermann, Frankfurt am Main, 2007, 357-390 and 391-425. On the level of Baltic legal science in European context see Luts-Sootak, M. Die baltische Privatrechtswissenschaft im 19. Jahrhundert zwischen deutscher Rechtswissenschaft und russischer Politik. - Rechtswissenschaft in Osteuropa. Studien zum 19. und frühen 20. Jahrhundert. Hrsg. von Z. Pokrovac. (Studien zur europäischen Rechtsgeschichte, Bd. 248.) Vittorio Klostermann, Frankfurt am Main, 2010, 165-209; Luts-Sootak, M. Zur Verortung des Baltischen Privatrechts (1864/65) unter den europäischen Privatrechtskodifikationen. - Rechtstransfer in der Geschichte. Internationale Fest- 
Perhaps with more time having passed since the end of the Soviet Union, more space is clear for scholars to think about Estonians who left the Baltic region in the nineteenth century for other places in the Russian Empire. Tiit Rosenberg finds that like other peoples in Europe, population growth among Estonians was greater than expansion of new labor opportunities in industry, and this pushed many to leave. ${ }^{42}$ Aivar Jürgenson's work focuses on Estonians who left for Siberia in the nineteenth century, many of whose descendants are still there. ${ }^{43}$ Using material from his research on Estonians outside of Estonia, he also discusses varying patterns of identification with a constructed "homeland" and draws attention to the dynamics in the reception of this emigration in Estonia, which became overwhelmingly positive only in the final decade of the century. ${ }^{44}$

Whereas Jürgenson primarily deals with peasant migrations, careers of Estonian intellectuals in the Russian Empire have been studied by Lea Leppik. She argues that even though it was difficult to assimilate into well-established structures of local society, many ambitious young people opted for the possibilities offered by the vast empire. People went to Russia as engineers, (military) doctors, chemists, headmasters of schools, veterinarians, land surveyors, postal and railway clerks, and Lutheran pastors. ${ }^{45}$ Also, Estonians in the capital have received attention in a monograph by Raimo Pullat. ${ }^{46}$ Interestingly, Estonian settlers on the Crimean Peninsula have been the subject of four collective volumes. ${ }^{47}$

schrift für Wilhelm Brauneder zum 75. Geburtstag. Hrsg. v. G. Hamza, M. Hlavačka, K. Takii. Peter Lang, Berlin, 2019, 219-243.

${ }^{42}$ Rosenberg, T. Eestlaste väljaränne 19. sajandil - 20. sajandi algul. Taust ja võrdlusjooni naabritega. - Eesti kultuur võõrsil: Loode-Venemaa ja Siberi asundused. Toim A. Tuisk. Eesti Kirjandusmuuseum, Tartu, 1998, 34-59.

${ }^{43}$ Jürgenson, A. Siberiga seotud: Eestlased teisel pool Uuraleid. Argo, Tallinn, 2006. See also Must, A. Siber ja Eesti: Jalaraua kõlin. Tartu Ülikooli Kirjastus, Tartu, 2012; Must, A. Eesti jälg Siberi agraarajaloos: Eesti kolonistide majanduselust 19. sajandi lõpul-20 sajandi algul. - Ajalooline ajakiri, 2007, 3/4 (121/122), 411-442.

${ }^{44}$ Jürgenson, A. On the formation of the Estonians' concepts of homeland and home place. - Culture and environments. Ed. by T. Anepaio. Eesti Rahva Muuseum, Tartu, 2004, 97-114. Jürgenson, A. Vaterlandsliebe und rollende Steine: Die öffentliche Rezeption der Auswanderung in Estland (zweite Hälfte des 19. und Anfang des 20. Jahrhunderts). - Wandel und Anpassung, 175-197. See also Jürgenson, A. Assimilatsionistidest transnatsionalistideni - rände ja integratsiooni uurimine 20. ja 21. sajandil. - Tuna, 2016, 2, 91-105; Jürgenson, A. Vabatahtliku ja sunniviisilise migratsiooni dihhotoomiast migratsiooni makro- ja mikroteooriate taustal. - Acta Historica Tallinnensia, 2008, 13, 92-117.

${ }^{45}$ Leppik, L. Social mobility and career patterns of Estonian intellectuals in the Russian empire. Historical Social Research, 2008, 33, 2, 42-62.

${ }^{46}$ Pullat, R. Lootuste linn Peterburi ja eesti haritlaskonna kujunemine kuni 1917. Estopol, Tallinn, 2004; see also on Estonians in Petersburg Province: Zaseckaja, M. L. Estnische Übersiedler im Gouvernement St. Petersburg von der zweiten Hälfte des 19. Jahrhunderts bis zum Anfang des 20. Jahrhunderts. - Nordost-Archiv, 1995, 4, 2, 533-549.

${ }^{47}$ Krimmi kogumik. [I] Konverentsi "140 aastat eestlust Krimmis" ettekanded. Toim J. Viikberg. Eesti Keele Sihtasutus, Tallinn, 2002; Krimmi kogumik. II: Konverentsi "Eestlased XIX-XXI sajandil Krimmis" ettekanded. Toim T. Tender, L. Viitol. Eesti Keele Sihtasutus, Tallinn, 2005; Krimmi kogumik. III. Toim H. Allik, T. Tender, Eesti Keele Sihtasutus, Tallinn, 2011; Eestlaste unistuste ja mälestuste Krimm. Pühendatud eestlaste Krimmi asumise 150. aastapäevale. Toim H. Treimann, P. Pääsuke, T. Toomet. SE \& JS, Tallinn, 2010. 
The work that opened up the study of associational life in nineteenth-century Estonia as a central aspect of social development was a collection written and compiled by Ea Jansen and her last student, Jaanus Arukaevu, and published in 1995. ${ }^{48}$ This work centered on associational groups of Estonians, but inspired further work on associations of the varying peoples living in Estonian lands. ${ }^{49}$ Attention to associational life and its connection to civil society in a multiethnic Estonia fit within a growing trend in historical research that sought to transcend national boundaries, as well as traditional periodization. The most thorough work of this type is Jörg Hackmann's Geselligkeit in Nordosteuropa.$^{50}$

\section{III.}

A significant development in the study of the formation of the Estonian nation in the nineteenth century has been to see the processes of change among the varying peoples of the Estonian lands as similar in nature. To be sure, Ea Jansen treasured the unique and particular character of Estonian culture and language. In one of her final articles she emphasizes that having their own linguistic sphere of communication and the freedom to choose who they wanted to be prevented the Estonians from complete Germanization or Russification. ${ }^{51}$ And to be sure, new, thorough studies of the rise and development of Estonian national consciousness still appeared. Mart Laar's Äratajad, ${ }^{52}$ for example, is a thorough, impressive empirical study, rooted in the approach to nation formation developed by Czech historian Miroslav Hroch in his immensely influential work Die Vorkämpfer der nationalen Bewegung bei den kleinen Völkern Europas (1968). And yet in the last article she published during her life, Jansen emphasized the similarities and parallels in the lives of the peoples in the Baltic region. ${ }^{53}$

At the same time, Kristi Kukk in her dissertation compares the emergence of national narratives in history writing in the Baltic countries and Scandinavian neighbors. ${ }^{54}$ Whereas theoretical contributions to nationalism studies from Estonian

48 Seltsid ja ühiskonna muutumine.

${ }^{49}$ For instance, see the essays in Vereinskultur und Zivilgesellschaft in Nordosteuropa. Regionale Spezifik und europäische Zusammenhänge. Hrsg. v. J. Hackmann. (Quellen und Studien zur baltischen Geschichte, 20.) Böhlau, Cologne, 2011.

${ }^{50}$ Hackmann, J. Geselligkeit in Nordosteuropa: Studien zu Vereinskultur, Zivilgesellschaft und Nationalisierungsprozessen in einer polykulturellen Region. (Veröffentlichungen des Nordost-Instituts, 19.) Harrassowitz, Wiesbaden, 2020

${ }^{51}$ Jansen, E. Sotsiaalne mobiilsus ja rahvuslik indentiteet. - Acta Historica Tallinnensia, 2003, 7, 15-30; see her collected articles: Jansen, E. Vaateid eesti rahvusluse sünniaegadesse. Ilmamaa, Tartu, 2004.

52 Laar, M. Äratajad. Rahvuslik ärkamisaeg Eestis 19. sajandil ja selle kandjad. Eesti Ajalooarhiiv, Tartu, 2005. See the popular-scientific version Idem. Rahvuse sünd. Eesti Rahva Muuseum, Tartu, 2016. See the critique on Laar's theoretical approach in Piirimäe, E. Eesti rahvuslus Euroopa kontekstis. - Ajalooline Ajakiri, 2007, 1 (119), 93-109.

53 Jansen, E. "Baltlus", baltisakslased, eestlased. - Tuna, 2005, 2, 25-44; 3, 31-42.

${ }^{54}$ Kukk, K. Väikerahvuste ajalookäsitluste genees ja narratiivid: Eesti võrdluses teiste Põhjala ja Baltikumi mittedominantsete rahvustega 19. sajandist kuni Teise maailmasõjani. (Dissertationes historiae Universitatis Tartuensis, 32.) Tartu Ülikooli Kirjastus, Tartu, 2013. 
historians on the period in question are rare, ${ }^{55}$ Kukk's comparative approach has not yet made a large impression on the field. Historians and literary scholars have instead in past decades increasingly studied cultural representations of Estonian nationalism ${ }^{56}$ and the biographies of the protagonists of the national awakening, ${ }^{57}$ including the generation of later political leaders..$^{58}$

Baltic Germans in Estonia in the nineteenth century are nearly exclusively studied by scholars with a perspective that brings together the tsarist-era provinces that today comprise Estonia and Latvia. Moreover, there is still a major gap in the historiography. We understand the world of the German nobility much better than the everyday life of merchants, and while we know a great deal about the so-called literati, tutors, teachers and professors, the so-called "little Germans" - underprivileged traders, craftsmen, workers, and peasants - are almost completely neglected by historians. ${ }^{59}$

An interesting debate recently arose about the seminal article by Tara Zahra on "national indifference" 60 and its relevance for the Germans in the Baltic provinces.

55 Petersoo, P. Reconsidering otherness: constructing Estonian identity. - Nations and Nationalism, 2007, 13, 1, 117-133; Piirimäe, E. Patriotism, rahvuslus, liberalism: Sissejuhatus. - Rahvuslus ja patriotism: Valik kaasaegseid filosoofilisi võtmetekste. Toim E. Piirimäe. Eesti Keele Sihtasutus, Tartu, 2009, 9-53; Piirimäe, E. Teoreetilisi perspektiive 19. sajandi eesti rahvuslusele. - Vene Impeerium ja Baltikum I, 167-191; Tamm, M. Rahvuste tegemine: Humanitaarteaduslik vaade. Keel ja Kirjandus, 2018, 1-2, 15-29.

56 See, e.g., Kaljundi, L., Kreem, T.-M. Ajalugu pildis - pilt ajaloos: Rahvuslik ja rahvusülene minevik eesti kunstis = History in images - image in history: National and transnational past in Estonian art. Eesti Kunstimuuseum, Tallinn, 2018; Rahvuskultuur ja tema teised. Toim R. Undusk. Underi ja Tuglase kirjanduskeskus, Tallinn, 2008; Jansen, E. Die Landschaft Estlands in der Auffassung estnischer Patrioten der Zeit des nationalen Erwachens. - Literatur und nationale Identität, Bd. 4: Landschaft und Territorium: Zur Literatur, Kunst und Geschichte des 19. und Anfang des 20. Jahrhunderts im Ostseeraum. Finnland, Estland, Lettland, Litauen und Polen. Hrsg. v. Y. Varpio, M. Zadencka. Almkvist \& Wiksell, Stockholm, 2004, 21-31. Latest research on the popular example of song festivals: Brüggemann, K., Kasekamp, A. 'Singing oneself into a nation'? Estonian song festivals as rituals of political mobilization. - Nations and Nationalism, 2014, 20, 2, 259-276; Hackmann, J. Sängerfeste in den russländischen Ostseeprovinzen vor 1914: Symbolische Ordnungen zwischen kulturellen Verflechtungen und Abgrenzungen. - Forschungen zur baltischen Geschichte, 2017, 12, 131-161.

${ }^{57}$ Besides Laar, M. Raamat Jakob Hurdast. Ilmamaa, Tartu 1995, see Laar, M. Äratajad, and the collected edition Geisteswissenschaften und Publizistik im Baltikum des 19. und frühen 20. Jahrhunderts. Hrsg. v. N. Angermann, W. Lenz, K. Maier. (Schriften der Baltischen Historischen Kommission, 11.) LIT, Berlin, 2011; Salupere, M. Postipapa. Mitmes peeglis, mitmes rollis. Raamat J. W. Jannsenist (1819-1890). Tallinn, Tänapäev, 2006; Salupere, M. Koidula: Ajastu taustal, kaasteeliste keskel, Tänapäev, Tallinn, 2017.

58 Jaan Poska oma ja meie ajas: Artikleid ja mälestusi. Toim K. Arjakas. Tallinna Linnaarhiiv, Tallinn, 2010; Karjahärm, T. Konstantin Päts: Poliitiline biograafia. I osa, Vabameelne opositsionäär (1874-1916). Rahvusarhiiv, Tartu, 2018; Aru, K. Jaan Tõnisson - rahvajuht ja riigivanem. 1. kd. Rahvusarhiiv, Tartu, 2019.

59 Angermann, N. Die Deutschbalten - eine Oberschicht? - Mythen der Vergangenheit. Realität und Fiktion in der Geschichte. Jörgen Bracker zum 75. Geburtstag. Hrsg. v. O. Pelc. V \& R unipress, Göttingen, 2012, 247-263.

${ }^{60}$ Zahra. T. Imagined non-communities: National indifference as a category of analysis. - Slavic Review, 2010, 69, 1, 93-119. 
Per Bolin and Christina Douglas argue that the term "indifference" is problematic because of its "connotations of inactivity." Instead, they propose terms such as "national ambiguity," "anationalism," or "hybridity," which indeed serve better in the multicultural setting of the Baltic provinces. ${ }^{62}$ If Bolin's and Douglas' conclusion that the Baltic Germans do not fit into any of these categories may apply to the elite groups to which the authors predominantly refer, Katja Wezel and Karsten Brüggemann argue that the German experience in the region and the options for orientation in a nationalizing world included more hybrid forms of identification, including a strong commitment to the Russian Empire as Vaterland. ${ }^{63}$

Heide W. Whelan focuses on home and family life of the Baltic German nobility both as a source of social cohesion and as an eventual weakness in coping with change in the Russian Empire. ${ }^{64}$ Opening new perspectives from a genderbased position, Anja Wilhelmi examines the lives of Baltic German women through an examination of everyday experiences (Lebenswelt) using autobiographical materials. She emphasizes a general sense of pride in the long German past in the region among women from differing social backgrounds and identifies women as important Kulturträgerinnen. Beginning in the final decades of the nineteenth century, Baltic German women, firmly established in their national views and politically motivated, entered public spaces, which provided them with broad public forums. As teachers, pupils, and members of associations, they were actively involved in creating, maintaining, and passing down national patterns of identity. ${ }^{65}$

Increasingly, scholars are examining local entanglements of cultures and the particular patterns of reception of the various ethnic groups. Ulrike Plath's monograph on German constructions of the other (i.e. the Estonians) and their "colonial discourses" 66 as reflected in German-language publications from the mid-eighteenth to the mid-nineteenth century is a pioneering work in this regard. She describes how

${ }^{61}$ Bolin, P., Douglas, C. 'National indifference' in the Baltic territories? A critical assessment. - Journal of Baltic Studies, 2017, 48, 1, 13-22, here: 15.

${ }^{62}$ Wezel, K. Introduction: German community - German nationality? Baltic German perceptions of belonging in the nineteenth and twentieth century. - Journal of Baltic Studies, 2017, 48, 1, 1-11, here 7.

${ }^{63}$ Brüggemann, K., Wezel, K. Nationally indifferent or ardent nationalists? On the options for being German in Russia's Baltic provinces, 1905-17. - Kritika: Explorations in Russian and Eurasian History, 2019, 20, 1, 39-62; discussing also a very fragmented understanding of belonging Plath, $\mathbf{U}$. Heimat: Rethinking Baltic German spaces of belonging. - Kunstiteaduslikke Uurimusi, 2014, 23, 3-4, 55-78.

${ }^{64}$ Whelan, H. Adapting to modernity: Family, caste and capitalism among the Baltic German nobility. Böhlau, Cologne, 1999.

${ }^{65}$ Wilhelmi, A. Lebenswelten von Frauen der deutschen Oberschicht im Baltikum (1800-1939): Eine Untersuchung anhand von Autobiografien. (Veröffentlichungen des Nordost-Instituts, 10.) Harrassowitz, Wiesbaden, 2008; Wilhelmi, A. Attempts of political participation versus loyalty manifestations? German women in the process of nationalization in the Baltic provinces of the Russian empire (1880-1920). - Journal of Baltic Studies, 2017, 48, 1, 23-37.

${ }^{66}$ Plath, U. Esten und Deutsche in den baltischen Provinzen Russlands: Fremdheitskonstruktionen, Lebenswelten, Kolonialphantasien 1750-1850. (Veröffentlichungen des Nordost-Instituts, 11.) Harrassowitz, Wiesbaden, 2011. 
the perception of the region and its inhabitants changed from being seen as a typical case of "eastern slavery" to an exemplary territory of German colonialism. Linda Kaljundi and Tiina-Mall Kreem have analyzed the cultural expression of this colonial mentality using the example of the historical drawings of Ludwig von Maydell. ${ }^{67}$ The interplay of political activities of differing ethnic communities is the object of articles by Tiit Rosenberg and Indrek Kiverik. ${ }^{68}$ There are also contributions by Estonian scholars on the intensive debates led predominantly by Baltic German experts on topics such as improvements in agriculture and the reform of jurisprudence. ${ }^{69}$

If the history of Estonian migration eastward into the Russian heartland in the tsarist period is considered part of Estonia's history (see above), then arguably the same approach should be taken for Baltic Germans from Estland and northern Livland provinces who left their homeland either temporarily or permanently for work and service in Russia. There remains much basic historical research yet to be undertaken in this area. Without more work on these people, the history of the Baltic Germans remains to some degree unknown, or is perhaps unaccountably seen as foreign to the history of the Baltic, as for example in the cases of the famous brother

${ }^{67}$ Friedrich Ludwig von Maydelli pildid Baltimaade ajaloost. Toim L. Kaljundi, T.-M. Kreem. Eesti Kunstimuuseum, Tallinn, 2013; Kaljundi, L., Kreem, T.-M. Friedrich Ludwig von Maydells Fünfzig Bilder aus der Geschichte der deutschen Ostsee-Provinzen Russlands: Zur Erforschung baltischer Geschichtsbilder. - Zeitschrift für Ostmitteleuropa-Forschung, 2017, 66, 4, 493-516. Valuable contributions can also be found in Kunstnik ja Kleio: Ajalugu ja kunst 19. sajandil $=$ The artist and Clio: History and art in the 19th century = Der Künstler und Klio: Geschichte und Kunst im 19. Jahrhundert. Toim. T.-M. Kreem. Eesti Kunstimuuseum, Tallinn, 2015.

${ }^{68}$ Kiverik, I. Die Deutschbalten und die jungen Nationalbewegungen in den Ostseeprovinzen des Russischen Reiches 1885-1914/17. - Nordost-Archiv, 2010, 19, 13-38; Rosenberg, T. Die Rezeption Carl Schirrens in der estnischen Historiographie. - Carl Schirren als Gelehrter im Spannungsfeld von Wissenschaft und politischer Publizistik. Hrsg. v. M. Garleff. (Baltische Seminare, 20.) Carl-Schirren-Gesellschaft, Lüneburg, 2013, 165-176; see also Pistohlkors, Gert v. "Restituierung der alten Zustände" oder zukunftsweisende Neuerungen? Schulbildung und der soziale Aufstieg von Esten und Letten vornehmlich in Livland im kontroversen öffentlichen Diskurs (1860 bis 1914). - Zeitschrift für Ostmitteleuropa-Forschung, 2018, 67, 1, 32-66; Kurilo, O. Deutschbalten und ihr Blick auf Russland und das Balitkum. - Russland an der Ostsee, 365-399; Karjahärm, T. The Image of Russia according to Estonian national movement leaders (until 1917). Ethnic images and stereotypes - where is the border line? (Russian-Baltic cross-cultural relations): Proceedings of the III International Scientific Conference on Political and Cultural Relations between Russia and the States of the Baltic region (Narva, October 20-22, 2006). Ed. by J. Nõmm. (Studia humaniora et paedagogica Collegii Narovensis, 2.) Tartu Ülikooli Narva kolledž, Narva, 2007, 189-204.

${ }^{69}$ Tammiksaar, E. Alexander Theodor von Middendorff und die Entwicklung der livländischen Gesellschaft in den Jahren 1860 bis 1885. - Zeitschrift für Ostmitteleuropa-Forschung, 2010, 59, 2, 147-185; Tammiksaar, E. Liivimaa Üldkasulik ja Ökonoomiline Sotsieteet ning teadmiste areng Eesti ala kõrgussuhete kohta 19. sajandil. - Teadusinnovatsioon tee praktikasse. Toim L. Leppik. (Tartu ülikooli ajaloo küsimusi, 41.) Tartu Ülikooli Ajaloo Muuseum, Tartu, 2013, 130-145; LutsSootak, M. Das Prinzip der Öffentlichkeit in den baltischen Justizreformdebatten in den sechziger Jahren des 19. Jahrhunderts. - Judiciary and society between privacy and publicity: 8th conference on legal history in the Baltic Sea area, 3rd-6th September 2015. Ed. by D. Janicka. Wydawnictwo naukowe Univerytetu Mikołaja Kopernika, Toruń, 2016, 433-462. 
and sister Alexander von Benckendorff (1781-1844) and Dorothea von Lieven (1785-1857) - he born in Tallinn and she in Riga. ${ }^{70}$

Another case in point is the history of famous explorers in Russian service such as Fabian Gottlieb von Bellingshausen (1778-1852) and others who were born in Estonia. Their expeditions have been studied by Erki Tammiksaar. ${ }^{71}$ The idea that due to the local German heritage the Estonian past has access not only to "Western" European culture but also to its bleaker aspects such as colonialism is quite new, but a recent exhibition in the Estonian Art Museum KUMU made exactly this point in juxtaposing an installation by a Maori artist, Lisa Reihana, about the first contact between colonizers and colonized with ethnographic sketches of varying peoples of the Russian Empire produced by expeditions led by Baltic German explorers. ${ }^{72}$ No doubt, the global conjuncture for topics such as colonialism and racism will lead to further research in this direction. ${ }^{73}$

One of the topics that has definitively received more attention in the past two decades than previously is the history of the Russian inhabitants of Estonia. First and foremost, the works of Sergei Isakov (1931-2013) deserve mention here; unfortunately, his major achievement, a history of Russians in Estonia in two volumes, was left unfinished with only the first volume published. ${ }^{74}$ Isakov's work is not a

${ }^{70}$ Recent biographies: Бибиков, Г. А. Х. Бенкендорф и политика императора Николая. Три квадрата, Москва, 2009 and Cromwell, J. L. Dorothea Lieven: A Russian Princess in London and Paris, 1785-1857. McFarland \& Co., Jefferson, N.C., 2007. See the descriptive and rather uncritical works: Гаврилов, С. Л. Остзейские немцы в Санкт-Петербурге. Российская империя между Шлезвигом и Гольштейном, 1710-1918. Центрполиграф, Москва, 2011; Илляшевич, В. Н. Прибалтийцы на российской дипломатической службе. Тарбеинфо, Таллинн, 2005; Илляшевич, В. Н. Прибалтийцы на российской государственной службе. Тарбеинфо, Таллинн, 2009.

${ }^{71}$ Tammiksaar, E. The Russian Antarctic Expedition under the command of Fabian Gottlieb von Bellingshausen and its reception in Russia and the world. - Polar Record, 2016, 52, 5, 578-600; Tammiksaar, E., Stone, I. A. Alexander von Middendorff and his expedition to Siberia (1842-1845). Polar Record, 2007, 43, 3, 193-216; Сухова, Н. Г., Таммиксаар, Э. Александр Федорович Миддендорф. К двухсотлетию со дня рождения. Нестор-История, Санкт-Петербург, 2015; Tammiksaar, E. Carl von Ditmar - ein Geologe aus Livland in russischen Diensten. -Reisen an den Rand des Russischen Reiches: Die wissenschaftliche Erschließung der nordpazifischen Küstengebiete im 18. und 19. Jahrhundert. Hrsg. von E. Kasten. Kulturstiftung Sibirien, Fürstenberg, 2013, 223-241; Tammiksaar, E. Gerhard Baron von Maydell (1835-1894) und die Bedeutung seiner Forschungen in Nordost-Sibirien. - Reisen an den Rand des Russischen Reiches, 243-267.

72 The conqueror's eye: Lisa Reihana's in pursuit of Venus. Tallinn, KUMU, 16.9.2019-26.1.2020.

${ }^{73}$ See the call for an integration of a (post)colonial concept into Estonian historiography Kaljundi, L., Plath, U. Eesti ajalookirjutus põimitud perspektiivist. - Tuna, 2017, 1, 2-6; Kaljundi, L., Plath, U. Serfdom as entanglement: Narratives of a social phenomenon in Baltic history writing. - Journal of Baltic Studies, 2020, 51, 3, 349-337.

${ }^{74}$ Исаков, С. Г. Путь длиною в тысячу лет. Русские в Эстонии. История культуры. Часть I. Ingri, Tallinn, 2008; Исаков, С. Г. Очерки русской культуры в Эстонии, Aleksandra, Tallinn 2005. See the comment Brüggemann, K. Baltimaade venelaste mälu ja identiteet: Ühe rahvusvähemuse ajaloo konstrueerimisest. - Tuna, 2012, 3, 30-37 and on Russians in Estonia in general Karjahärm, T. Ida ja Lääne vahel. Eesti-Vene suhted 1850-1917. Eesti Entsüklopeediakirjastus, Tallinn, 1998, 19-61. In contrast to the academic approach of Isakov, another work on the topic by a Russian cannot hide the imperial nostalgia of its author: Илляшевич, В.: Русские судьбы Эстонии. Integratsiooni Toetuse Fond, Таллин 2007 (transl. as Iljaševitš, V. Eestimaa venelaste saatused. Tarbeinfo, Tallinn, 2013). 
social history of an ethnic minority; as a literary scholar he focused on literary traces of Russians who have lived in Estonia or who visited the region. ${ }^{75}$ Thus emerged also Isakov's interest in Estonia as a tourist destination for Russians, which was developed by other Estonian-Russian scholars. ${ }^{76}$ An impressive collected edition supervised by Irina Pärt has recently drawn attention to research being conducted on the Orthodox Church in the Baltic provinces ${ }^{77}$ which for years has been continued first and foremost by the late Aleksandrs Gavrilinš (1953-2019).$^{78}$ Fresh light on the history of conversions to Orthodoxy during the 1840 is provided by Daniel C. Ryan. ${ }^{79}$ Of course, the history of the Orthodox Church is tightly interwoven with the empire and its traces in the local past, which we discuss in the next section.

IV.

Sergei Isakov wrote extensively beginning in the 1960s about cross-cultural relations between the empire and its Baltic provinces. During recent decades this interconnectedness ${ }^{80}$ has been most explicitly researched by Toomas Karjahärm, who also has dealt intensively with new international currents in the research of the multinational Russian Empire. ${ }^{81}$ His two partly overlapping collections of documents,

\footnotetext{
${ }^{75}$ Recent works in this spirit include Kisseljova, L. Eesti-vene kultuuriruum. Tlk M. Salupere jt. Tartu Ülikooli Kirjastus, Tartu, 2017; Салупере, М. Ф. В. Булгарин в Лифляндии и Эстляндии. - Русские в Эстонии на пороге XXI века. Прошлое, настоящее, будущее. Сборник статей. Сост. В. Бойков, Н. Бассель. Ingri, Tallinn, 2000, 146-161. Bulgarin's feuiletons and letters on the Baltic provinces have recently been translated into Estonian: Bulgarin, F. Kirjad Karlova mõisast. Tlk M. Salupere. Ilmamaa, Tartu, 2019.

${ }^{76}$ Issakov, S. Дачные места на Нарвском взморье (конец XIX - начало XX в.): отражение в литературе и искусстве. - The dacha kingdom: Summer dvellers and dwellings in the Baltic area. Ed. by N. Baschmakoff, M. Ristolainen. Aleksanteri Institute, Helsinki, 2009, 299-322; see also Меймре, А., Белобровцева, И., Кузмин, Д., Пономарева, Г. Топография культуры: Деятели русской культуры - дачники в Эстонии. Флинта, Москва, 2011.

77 Православие в Прибалтике: Религия, политика, образование 1840-е-1930-е гг. Отв. ред. И. Пярт. Издательство Тартуского университета, Тарту, 2018; Paert, I. Orthodox education in the Lutheran environment 1840-1917. - Reformation in Nordosteuropa. Ed. by S. Rimestad (NordostArchiv 25/2016.) Nordost-Institut, Lüneburg, 2017, 74-91.

${ }^{78}$ See especially Гаврилин, А. Очерки истории Рижской епархии. XIX век. Filokalija, Riga, 1999.

${ }^{79}$ Ryan, D. C. Religious conversion and the problem of commitment in Livland Province, $1850 \mathrm{~s}-$ 1860s. - Ajalooline ajakiri, 2007, 3/4 (121/122), 369-392; Ryan, D. C. Rumor, belief and contestation amid the conversion movement to Orthodoxy in Northern Livonia, 1845-1848. - Folklore, 2004, 28, 7-23. See Brüggemann, K. Ein Fall von "Verschmelzung" mit Russland? Zur nationalen Frage in der Orthodoxen Kirche der Ostseeprovinzen im späten Zarenreich. - Wandel und Anpassung, 89-111. Research on the peasants in this decade benefits from a rich publication of documents: Talurahvaliikumine Eestis aastail 1845-1848. Dokumentide kogumik. Kd 1-2. Toim A. Traat Eesti Vabariigi Arhiiviamet, Eesti Ajalooarhiiv, Tallinn, 1991.

${ }^{80}$ Brüggemann, K., Woodworth, B. Entangled pasts - Russia and the Baltic region. - Russland an der Ostsee, 3-26.

${ }^{81}$ See first and foremost the two monographs Karjahärm, Ida ja Lääne vahel; Karjahärm, T. Vene impeerium ja rahvuslus: Moderniseerimise strateegiad. Argo, Tallinn, 2012, and the articles
} 
one in Estonian and one in Russian, provide researchers with valuable material on center-periphery relations in the final decades of the nineteenth century and in the early twentieth century. ${ }^{82}$ Scholars have begun to deal with the obvious Swedish heritage and its reception in the Russian Empire, especially in terms of jurisprudence $^{83}$ and with the officials who were sent from Russia to the Baltic provinces. ${ }^{84}$ Underappreciated, though, is the fact that these men served as the embodiment of the empire since many of them had served in many different places in the realm of the Romanovs. ${ }^{85}$

One of the important aspects of "imperiality" in the local life of the Baltic provinces was military service in the Tsar's army. Unfortunately, with no "military turn" in sight, neither international nor national experts currently focus on this topic, even if no one doubts the strategic significance of the region for the defense of the imperial capital. ${ }^{86} \mathrm{~A}$ small number of Estonian professional historians are active in this field. The leading expert, Tõnu Tannberg, is by far the most productive author in the field of military history from the Napoleonic Wars to the Crimean War and even beyond, while also a prolific writer on the years of Sovietisation. Tannberg has paid significant attention to the imperial recruiting system and its consequences for Estonian men throughout the cen-

\footnotetext{
Karjahärm, T. Aleksei Miller ja "uus impeeriumi ajalugu”. - Tuna, 2011, 3, 136-141; Karjahärm, T. Terminology pertaining to ethnic relations as used in late Imperial Russia. - Acta Historica Tallinnensia, 2010, 15, 24-50; Karjahärm, T. Venelased ja mittevenelased: terminoloogiline ekskurss Vene impeeriumi rahvussuhetesse. - Eesti ajaloost 19.-20. sajandil, 163-211; see the comment Brüggemann, K. Der imperial turn in Estland: Anmerkungen zu Toomas Karjahärms "Das Russische Imperium und der Nationalismus". - Forschungen zur baltischen Geschichte, 2013, 8, 228 235. Worth mentioning for its broader discussion of the "nationalization" of the Russian empire is a collected edition produced by Estonian scholars Indrek Jääts and Erki Tammiksaar: Проникновение и применение дискурса национальности в России и СССР в конце XVIII - первой половине ХХ вв. Ред. И. Яатс, Э. Таммиксаар. Эстонский национальный музей, Тарту, 2011.

${ }^{82}$ Venestamine Eestis 1880-1917: Dokumente ja materjale. Toim T. Karjahärm. Riiklik Eksami- ja Kvalifikatsioonikeskus, Tallinn, 1997; Имперская политика России в Прибалтике в начале XX века: Сборник документов и материалов. Сост. Т. Карьяхярм. Eesti Ajalooarhiiv, Tartu, 2000.

${ }^{83}$ Luts-Sootak, M. The Swedish court and appeal system in the Russian empire: The case of Livland in 1710-1889. - Suum cuique tribuere: Legal contexts, judicial archetypes and deep-structures regarding courts of appeal and judiciaries from early modern to late modern Europe. Ed. by K. Å. Modéer, M. Sunnqvist. (Rättshistoriska studier, 27.) Olin Foundation, Stockholm, 2018, 217-243.

${ }^{84}$ See fn 21; Leppik, L. Die Generalgouverneure im Baltikum - Instrumente zur Vereinheitlichung des Russischen Imperiums oder ein Schutz der baltischen Sonderordnung? - Estland und Russland, 53-76; Brüggemann, K. Representing empire, performing nation? Russian officials in the Baltic provinces (late 19th/early 20th centuries). - Ab Imperio, 2014, 15, 3, 231-266; Brüggemann, K. Imperiale und lokale Loyalitäten im Konflikt: Der Einzug Russlands in die Ostseeprovinzen in den 1840er Jahren. - Jahrbücher für Geschichte Osteuropas, 2014, 62, 3, 321-344.

${ }^{85}$ As an instructive exception to this rule, see the collected edition Eliten im Vielvölkerreich. Imperiale Biographien in Russland und Österreich-Ungarn (1850-1918) = Elites and empire: Imperial biographies in Russia and Austria-Hungary (1850-1918). Hrsg. v. T. Buchen, M. Rolf. De Gruyter Oldenbourg, Berlin, 2015.

${ }^{86}$ Tannberg, T. Eesti ala Venemaa sõjaväesüsteemi integreerimise tagajärjed. Kas "kahesaja-aastane rahuaeg" või verekümnis impeeriumi altarile? - Tuna, 2010, 3, 52-67; Tannberg, T. Eesti mees Vene kroonus. Ilmamaa, Tartu, 2011.
} 
tury ${ }^{87}$ Unfortunately, there is no historian in sight poised to continue this track. The early passing of Rein Helme (1954-2003), the leading expert on the period of the Napoleonic Wars, ${ }^{88}$ has left a void. Concerning military history one might additionally mention the works of Mati Kröönström in producing a social portrait of Estonian officers serving in the imperial army during the last decades of the nineteenth century. ${ }^{89}$ The Estonian Yearbook of Military History since 2011 offers collaborative articles from the national and international community, but it has a focus on the twentieth century and is not devoted exclusively to the Baltic countries. ${ }^{90}$ Predominantly, Estonian authors discuss Estonian men in the Russian Army. What we lack is more thorough information, e.g., on the dispersion of the imperial army on Estonian soil or civil-military relations on the spot. ${ }^{91}$

Not the least because of Cold War discourses and local experiences during the second half of the twentieth century, "Russification" (venestamine) is still one of the key concepts used to this day in Estonian historiography as a negative marker for the later part of the imperial period. However, Ea Jansen showed how diverse the reception of the reform policy under Alexander III was in Estonia. ${ }^{92}$ Even

${ }^{87}$ Tannberg, T. Maakaitseväekohustus Balti kubermangudes 19. sajandi 1. poolel (1806-1856). Eesti Ajalooarhiiv, Tartu, 1996; Tannberg, T. Warten auf Napoleon: Die Landmiliz der Jahre 1806-1807 in den baltischen Gouvernements des Zarenreichs (Tartuer historische Studien, 4.) Dr. Kovač, Hamburg, 2015; Tannberg, T. "Numerus clausus" Vene armees. Usulistest ja rahvuslikest piirangutest tsaariarmee komplekteerimisel 19. sajandi teisel poolel. - Ajalooline ajakiri, 2000, 3 (110), 35-42; Tannberg, T. The Baltic Provinces during the Crimean War. - Sõnasse püütud minevik. In honorem Enn Tarvel. Koost P. Raudkivi, M. Seppel. Argo, Tallinn, 2009, 252-282; Tannberg, T. Das Imperium und sein Grenzgebiet: Hauptzüge und Eigenarten der Rekrutenordnung in den baltischen Gouvernements 1796-1874. - Festschrift für Vello Helk zum 75. Geburtstag: Beiträge zur Verwaltungs-, Kirchen- und Bildungsgeschichte des Ostseeraumes. Hrsg. v. E. Küng, H. Tamman. Eesti Ajalooarhiiv, Tartu, 1998, 297-332.

${ }^{88}$ Helme, R. 1812. aasta Eestis ja Lätis: Monograafia. Olion, Tallinn, 1990, and (posthumously published) Helme, R. Kindralfeldmarssal Barclay de Tolly. Eesti Entsüklopeediakirjastus, Tallinn, 2006; see also Helme, R. Unter siegreichen Fahnen: Die deutschbaltischen Offiziere in den Kriegen unter Katharina II., Paul I. und Alexander I. - Zwischen Aufklärung und Baltischem Biedermeier. Hrsg. v. O.-H. Elias. (Baltische Seminare, 12.) Carl-Schirren-Gesellschaft, Lüneburg, 2007, 99-130. Only recently, new research on the Napoleonic era was initiated by the collected edition: 200 aastat Napoleoni sõjakäigust Venemaale ja selle mõju Läänemere maadele $=$ Napoleonic Wars and the Baltic Sea region: 200 years since French invasion of Russia. Toim T. Hiio. (Estonian Yearbook of Military History, 3.) Tallinna Ülikooli Kirjastus, Tallinn, 2013. See also the very recent dissertation Gornischeff, F. Venemaa suhted Preisimaaga Napoleoni sõdade ajal baltisaksa päritolu diplomaatide tegevuse näitel (1806-1812). Tartu Ülikooli Kirjastus, Tartu 2020 (Dissertationes historiae Universitatis Tartuensis, 49.)

${ }^{89}$ Kröönström, M. Tsaariarmees teeninud eesti soost kaadriohvitseride sotsiaalsest päritolust. - Ajalooline Ajakiri 2000, 3 (110), 43-50; Kröönström, M. Eesti rahvusest kaadriohvitserid Vene armees aastail 1870-1917. - Vene aeg Eestis, 317-344.

${ }^{90} \mathrm{http}: / /$ publications.tlu.ee/index.php/eymh.

${ }^{91}$ This is briefly dealt with in Tannberg, T. Tallinna garnison. - Tallinna ajalugu. III, 125-135.

92 Jansen, E. Aleksander III venestusreformid ja Eesti avalikkus. - Acta Historica Tallinnensia, 1999, 3, 39-66; Jansen, E. Tsaristlik tsensuur ja eesti ajakirjandus venestamisajal (1880.-1890. aastad). Tuna, 2000, 2, 42-60; Jansen, E. Eesti seltside saadikute audients Vene keisri juures 1881. aastal ja nende märgukiri kui katse osaleda "suures poliitikas". - Acta Historica Tallinnensia, 1997, 1, 93-116. 
Mart Laar recently suggested that from the perspective of the Estonian national movement, "Russification" may have in part benefitted emerging national elites in opening the way into state service and modernized administration, and he called for more research. ${ }^{93}$ And indeed, recent studies on the imperial phenomenon of Russification call for a more differentiated approach..$^{94}$ Legal historian Marju Luts-Sootak has demonstrated that despite the Baltic German argument according to which the Russian government under Alexander III unilaterally violated the promises of the capitulations of 1710 , both sides in fact had previously had annuled these old regulations with new ones, e.g. the Baltic Private Law from $1865 .{ }^{95}$ In his recent monograph, Karsten Brüggemann analyzes the various Russian understandings of the reforms and presents an overview of the impact of Russian nationalism on the changing perceptions of Russian elites toward the Baltic provinces from the early nineteenth to the early twentieth century. ${ }^{96}$ The reflections of these changing perceptions in nineteenth-century Russian-language historiography on the Baltic provinces have been analyzed by Tiit Rosenberg. ${ }^{97}$

\section{V.}

This brief historiographical overview cannot pay adequate attention to all the contributions from specialists in the various fields of cultural studies, ${ }^{98}$ litera-

${ }^{93}$ Laar, Rahvuse sünd.

${ }^{94}$ See. e.g., Kappeler, A. Hiliskeiserlik Vene impeerium moderniseerumise ja traditsiooni vahel. - Vene impeerium ja Baltikum I, 51-92; Miller, A. Venestus või venestused. - Vene impeerium ja Baltikum I, 33-50; Miller, A. Identiteet ja lojaalsus Vene impeeriumi keelepoliitikas. - Vikerkaar, 2012, 10/11, 102-116; Weeks, T. Russification: Word and practice 1863-1914. - Proceedings of the American Philosophical Society, 2004, 148, 471-489; Brüggemann, K. Lõpp venestusele: Ühe vaieldava uurimisparadigma kriitika. - Vene Impeerium ja Baltikum II, 360-374; Brüggemann, K. Als Land und Leute "russisch" werden sollten: Zum Verständnis des Phänomens der "Russifizierung" am Beispiel der Ostseeprovinzen des Zarenreichs. - Kampf um Wort und Schrift: Russifizierung in Osteuropa im 19.-20. Jahrhundert. Hrsg. v. Z. Gasimov. Vandenhoeck \& Ruprecht, Göttingen, 2012, 27-49.

${ }^{95}$ Luts-Sootak, M. Die baltischen Kapitulationen von 1710 und die Gesetzbücher des 19. Jahrhunderts. - Die baltischen Kapitulationen von 1710. Kontext - Wirkungen - Interpretationen. Hrsg. v. K. Brüggemann, M. Laur, P. Piirimäe. (Quellen und Studien zur baltischen Geschichte, Bd. 23.) Böhlau Verlag, Köln et al., 2014, 153-182; on the development of this private law see her dissertation: Luts-Sootak, M. Juhuslik ja isamaaline: F. G. v. Bunge provintsiaalõigusteadus. (Dissertationes iuridicae Universitatis Tartuensis, 3.) Tartu Ülikooli Kirjastus, Tartu, 2000.

${ }^{96}$ Brüggemann, K. Licht und Luft des Imperiums: Legitimations- und Repräsentationsstrategien russischer Herrschaft an der Ostsee im 19. und frühen 20. Jahrhundert. (Veröffentlichungen des Nordost-Instituts, 21.) Harrassowitz, Wiesbaden, 2018; Brüggemann, K. The Baltic provinces and Russian perceptions in late imperial Russia. - Russland an der Ostsee, 111-141.

${ }^{97}$ Rosenberg, T. Die russische baltische Historiographie in der zweiten Hälfte des 19. und zu Beginn des 20. Jahrhunderts. - Estland und Russland, 77-108.

${ }^{98}$ For the field of German-Baltic cultural entanglements see e.g. Baltisch-deutsche Kulturbeziehungen vom 16. bis 19. Jahrhundert. Hrsg. v. R. Bičevskis, J. Eickmeyer, A. Levans et al. Bd. 1: Zwischen Reformation und Aufklärung. (Akademie-Konferenzen, 28.) Universitätsverlag Winter, Heidelberg, 2017; Bd. 2: Zwischen Aufklärung und nationalem Erwachen. (Akademie-Konferenzen, 29.) Universitätsverlag Winter, Heidelberg 2019. See also Umweltphilosophie und Landschaftsdenken im 
ture, ${ }^{99}$ art, ${ }^{100}$ music, ${ }^{101}$ architecture, ${ }^{102}$ photography, ${ }^{103}$ or sport. ${ }^{104}$ As an interdisciplinary - and transnational - area of study, Estonia's experience during the nineteenth century has benefited from collaboration among scholars active in Baltic Studies, the study of Europe's northeast and the Russian Empire, and a wide range of thematic fields such as nationalism, colonialism, rural and urban social and economic development, civil society, migration and, increasingly, transnationalism. In all of these fields Estonian scholars in the past two decades have integrated international discussions into their argumentation and have themselves taken part in these debates. Past differences in views held by (Baltic) German and Estonian scholars have largely themselves become history and await researchers. Cooperation has also become customary between scholars from Finland, Germany, North America, Latvia and other Eastern European countries. One might sense a relative lack of close partnership with Russian colleagues, but apart from the current complicating political circumstances, the number of historians in Russia dealing with the Pribaltika in the nineteenth century is rather small. ${ }^{105}$

baltischen Kulturraum = Environmental philosophy and landscape thinking. Hrsg. V. L. Lukas, U. Plath, K. Tüür. (Collegium litterarum, 24.) Underi ja Tuglase Kirjanduskeskus, Tallinn, 2011; Eestimaa Provintsiaalmuuseum ja muuseumitraditsiooni algus Eestis. (Varia historica, 7.) Toim T. Liibek, Eesti Ajaloomuuseum, Tallinn, 2013.

99 For example, see Politische Dimensionen der deutschbaltischen literarischen Kultur. Hrsg. V. L. Lukas, M. Schwidtal, J. Undusk. (Schriften der Baltischen Historischen Kommission, 22.) LIT, Berlin, 2018; Das Baltikum als Konstrukt (18.-19. Jahrhundert): Von einer Kolonialwahrnehmung zu einem nationalen Diskurs. Hrsg. v. A. Sommerlat-Michas. Königshausen \& Neumann, Würzburg, 2015; Autogenees ja ülekanne: Moodsa kultuuri kujunemine Eestis. Toim R. Undusk. Underi ja Tuglase Kirjanduskeskus, Tallinn, 2014.

${ }^{100}$ See the general works including chapters on architecture in Eesti kunsti ajalugu, 3: 1770-1840. Toim J. Maiste. Eesti Kunstiakadeemia, Tallinn, 2017; Eesti kunsti ajalugu, 4: 1840-1900. Toim J. Keevallik. Eesti Kunstiakadeemia, Tallinn, 2019.

${ }^{101}$ Musikleben des 19. Jahrhunderts im nördlichen Europa: Strukturen und Prozesse. Hrsg. v. T. Siitan, K. Pappel, A. Sõõro. (Studien und Materialien zur Musikwissenschaft, 60.) Georg Olms Verlag, Hildesheim, 2010; Musik im Baltikum. Hrsg. v. H. Scheunchen. (Baltische Seminare, 21.) CarlSchirren-Gesellschaft, Lüneburg, 2019. See also the journal Res Musica (https://resmusica.ee).

${ }^{102}$ See, e.g., Hein, A. Eesti mõisaarhitektuur. Historitsismist juugendini $=$ Gutsarchitektur in Estland. Vom Historismus bis zum Jugendstil. Hattorpe, Tallinn, 2003; Tohvri, E. Valgustusideede mõju Tartu arhitektuurikultuurile 19. sajandi alguses. (Dissertationes historiae Universitatis Tartuensis, 18) Tartu Ülikooli Kirjastus, Tartu, 2009; Kreem, T.-M. Viisipäraselt ehitatud. Luterlik kirikuehitus, -arhitektuur ja -kunst Eestis Aleksander II ajal (1855-1881). Eesti Kunstiakadeemia, Tallinn, 2010.

${ }^{103}$ Liibek, T. Fotograafiakultuur Eestis 1839-1895. (Tallinna Ülikooli humanitaarteaduste dissertatsioonid, 24.) Tallinna Ülikool, Tallinn, 2010; Liibek, T. Die Fotografie als Spiegel des Alltagslebens in Estland im 19. Jahrhundert. - Zeitschrift für Ostmitteleuropa-Forschung, 2017, 66, 4, 558-575.

${ }^{104}$ Antons, K., Voolaid, K. Eesti spordi lugu. Eesti Spordi- ja Olümpiamuuseum, Tartu, 2018 (19-57 on nineteenth century); more specifically Brüggemann, K. Imperial careers and national recollection: Baltic wrestlers and the organization on national sports in the late Tsarist empire (using the example of Estonia). - Euphoria and exhaustion: Modern sport in Soviet culture and society. Ed. by N. Katzer, S. Budy, A. Köhring, M. Zeller. Campus, Frankfurt am Main, 2010, 133-157.

${ }^{105}$ T. Tannberg and K. Brüggemann are connected to the book series "Россия и Балтия" published regularly by the Institute of General History at the Russian Academy of Science since 2000; a ninth number is currently in preparation. 
As this overview has tried to show, there is lively interest in the nineteenth century among Estonian scholars and their colleagues from abroad. The scope of topics is wide, and we expect there will be keen interest in the historical development of Estonian national culture also in the years to come. Three critical factors, however, should be briefly touched upon here in conclusion. As already mentioned, the number of historians of Estonia is so small that future research on questions such as school life (education) and industrialization (capitalist development) might hang on a thin thread if younger scholars do not continue the work of their forerunners. Second, the growing danger in Estonia that future researchers will lack the necessary skills in reading German and Russian threatens to limit their ability to understand fully the conditions of the nineteenth century. Third, continuity of research requires financial support. The ubiquitous dependence on external financing and the importance of "projects" endangers the sustainability of historical research, and the pressure to follow research agendas aligned only with the latest trends in international historiography often thwarts more general research on problems not yet addressed in local history writing.

And yet, the writing of the history of a place and of its people is never final. History does not end since the questions we want - and need - to ask of the past are always influenced by the questions we ask of ourselves and of our world today. We as historians who have given much of our lives to living in and studying these lands and peoples look forward to the questions that in this twenty-first century will be asked about the formative nineteenth century and to the dialogues and that will continue among historians and all those who care about this time and its peoples.

\section{ACKNOWLEDGMENTS}

The preparation of this article has been supported by the Estonian Research Council's research project IUT31-6 "A Transnational Setting for Estonian History: Transcultural Entanglements, International Organisations and Transborder Migrations (16th-21st Centuries)."

\section{EESTI UUSAJA UURIMINE 21. SAJANDIL}

\section{Karsten BRÜGGEMANN ja Bradley D. WOODWORTH}

Artiklis antakse ülevaade 19. sajandi Eesti ajalugu käsitlevatest Eesti ja rahvusvahelisest uurimusest, mis pärinevad ajast alates taasiseseisvumisest 1991. aastal, pöörates erilist tähelepanu 21. sajandil valminud töödele. Lisaks olulisemate uurimissuundade käsitlemisele toovad autorid välja ka rea teemasid, mis alles ootavad uurijate tähelepanu.

Lühikeses sissejuhatuses 19. sajandit hõlmavatest ajalookäsitlustest märgivad autorid, et vaja oleks rohkem Eesti üldajalugu käsitlevaid teoseid Eesti autorite su- 
lest. Artikli teises osas, mis annab ülevaate sotsiaal- ja majandusajaloost, keskendutakse töödele, mis uurivad tsaariaegse Eesti sotsiaal-, eriti talurahva- ja agraarajalugu. Selles vallas on üks olulisemaid uusi suundumusi pöörata tähelepanu talupoegade endi vaatenurgale, selle asemel et vaadelda neid pelgalt olude mängukannina. Linnade kontekstis on uuritud kujunevat haritlaskonda, aga ka laienevat koolisüsteemi alates algkoolidest kuni Tartu ülikoolini välja. Viimastel aastakümnetel on teadustööde fookuses olnud ka laienev seltsielu ja kodanikuühiskond. Erilist tähelepanu pööratakse artiklis Ea Janseni viimasele raamatule, „Eestlane muutuvas ajas: Seisusühiskonnast kodanikuühiskonda“, mis ilmus 2007. aastal postuumselt ja milles autor uuris eestlaste ja baltisakslaste suhet ajal, mil eestlased muutusid avalikus elus aina aktiivsemaks. Vastupidiselt varasematele uuringutele rõhutas Jansen ühist keskkonda, mis ühendas erineva etnilise taustaga inimesi, isegi kui sotsiaalne võõrandumine jäi autori sõnul püsima, sest mõlemad pooled muutusid „millekski muuks” ega hoolinud üksteisele lähenemisest.

Uusaja ajalookirjutust rikastavad kaks uut ülevaadet Tallinna ajaloost, mis keskenduvad 19. sajandile, kuid eesti linnakeskkondade üldajalugu on veel endiselt kirjutamata. Rohkem uurimusi on vaja Eesti proletariaadist, mis autorite väitel on endiselt peidetud klassivõitluse ajaloo nõukogudeaegse idealiseerimise seina taha. Üsna intensiivselt on uuritud Baltikumist lahkunud ja ida poole, Vene impeeriumi aladele ümber asunud eestlasi, kuid rohkem tähelepanu vajaks Eesti-sisene ränne maapiirkondadest linnadesse.

Artikli kolmandas, rahvusi käsitlevas osas toovad autorid välja uue suundumuse, mille kohaselt nähakse sarnasusi mitmerahvuselise Eesti eri rahvuste seas toimunud muutuste vahel, samal ajal on leitud ka uusi lähenemisviise erinevate rahvusrühmade mõistmiseks. Baltisakslaste osas on täheldatud rahvuslik-poliitilise lojaalsuse hübriidsust. Viljakaks on osutunud ka baltisaksa Lebenswelt'i vaatlemine kolonialismidiskursuse kontekstis. Paaril viimasel aastakümnel on pööratud suuremat tähelepanu Eesti venekeelsele elanikkonnale. Autorid soovitavad rohkem uurida ka mujal Venemaa impeeriumis elanud ja töötanud, samuti madalamatesse sotsiaalsetesse kihtidesse kuulunud baltisakslasi, kellest on siiani teada võrdlemisi vähe.

Artikli neljas osa vaatleb uuemaid uurimusi Eestist Vene impeeriumi koosseisus. Eriti viljakas uurimisvaldkond on olnud Balti provintsidest pärit inimeste sõjaväeteenistuse imperiaalne aspekt. Selles valdkonnas on keskne roll Tõnu Tannbergil, kes on kirjutanud mitu uurimust 19. sajandi sõjaajaloost (avaldades samal ajal ka arvukalt kirjutisi Eesti sovetiseerimise kohta). Laiemasse 19. sajandi tsaariimpeeriumi ajalukku paigutab Eesti Karsten Brüggemanni vastne uurimus Venemaa eliidi vaatest Balti provintsidele.

Artikli kokkuvõttes osutavad autorid, et viimastel aastakümnetel on Eesti ajaloolased olnud osalised rahvusvahelistes teadusdiskussioonides ega ole keskendunud vaid ühele rahvusrühmale. Rahvusvaheline teaduskoostöö on muutunud igapäevaseks, ehkki rohkem võiks olla suhtlemist ja mõttevahetust Venemaa kolleegidega. Nimetada tuleb siiski kolme muret seoses Eesti ajalookirjutuse tulevikuga. Esiteks on teadlaste arv väike ja seega on põlvkondlik järjepidevus ajaloolaste 
töös väga oluline. Teiseks, kuna nii allikate kui teadustööde mõistmiseks on vajalik saksa ja vene keele oskus, siis selle jätkuv taandumine paneb ohtu tulevaste ajaloopõlvkondade võime mõista piisavalt 19. sajandi olusid. Kolmandaks, ajaloolaste jätkuv sõltuvus välisest rahastamisest ja keskendumine üksikprojektidele võib ohustada pikaajalisi alusuuringuid, kuna sunnib teadlasi kiire finantseerimise lootuses järgima pigem uuemaid moetrende. 